\title{
PUSAT PENYEMBUHAN ORANG STRES DI CIKINI
}

\author{
Patricia Setiadi ${ }^{1)}$, Martin Halim ${ }^{2)}$ \\ 1) Program Studi S1 Arsitektur, Fakultas Teknik, Universitas Tarumanagara, patriciasetiadi14@gmail.com \\ 2) Program Studi S1 Arsitektur, Fakultas Teknik, Universitas Tarumanagara, martinhalim90@gmail.com
}

\begin{abstract}
Abstrak
Generasi Milenial (Gen Y) merupakan generasi yang lahir antara tahun 1981 - 1994 dan menjadi populasi usia produktif terbanyak saat ini. Dengan perkembangan teknologi mengubah gaya hidup menjadi serba cepat dan instan. Dengan perkembangan modernisasi dan globalisasi mengubah kehidupan sosial dari masyarakat kompleks menjadi multi kompleks dengan gaya hidup serba cepat. Isu mengenai ketimpangan kesehatan juga menempati peringkat kedua terpenting bagi generasi milenial berdasarkan Vision Critical (2016). Dengan populasi penduduk berpendapatan menengah semakin meningkat, maka kebutuhan juga semakin meningkat dan mengakibatkan perubahan perilaku konsumsi di Indonesia. Generasi milenial ini mengalihkan pengeluarannya dari kategori Fast Moving Consumer Good (FMCG) tradisional seperti makanan dan minuman ke berbagai kategori yang bersifat sekunder. Generasi milenial merasa bahwa tingkat stres dalam kehidupan sehari hari semakin meningkat sehingga muncul kebutuhan untuk melarikan diri dari kondisi stres. Dengan menghadirkan sebuah arsitektur yang berfungsi sebagai wadah sarana kesehatan khusus kejiwaan bagi generasi milenial dengan metode psikologis, rekreasi, dan bersifat menghibur diharapkan dapat membantu meredakan kepenatan sehari - hari. Dengan menggunakan pendekatan pattern language oleh Christopher Alexander dipadukan dengan healing architecture dan penyebaran kuesioner, desain akan menekankan pada konektivitas antar bangunan dengan ruang transisi dan memasukkan kembali unsur alam sebagai penyatuan lingkungan alami dan buatan ke dalam bangunan sehingga memberikan pengalaman ruang yang berbeda. Terdapat healing park yang difungsikan sebagai daerah pubik untuk terapi secara alamiah dan ditanami beberapa jenis tanaman herbal yang dapat membantu menyembuhkan secara psikologis dan diharapkan dapat menghilangkan kepenatan sehari - hari.
\end{abstract}

Kata kunci: Cikini; Milenial; Penyembuhan; Stres; Terapi

\begin{abstract}
Millennials (Gen Y) are the generation born between the year of 1981-1994 and currently become the biggest productive age group population. Advance technology turns lifestyle into fast paced and instant. Development of modernization and globalization alters social community from complex society to multi complex society with fast paced life. For millennials, the issue of health inequality is also ranked second most important. With the increase of middle income population also comes the increasing demand of necessity resulting in changes of consumption behavior in Indonesia. Millennials switch their expense from traditional category Fast Moving Consumer Good (FCMG) such as foods and beverages to various secondary categories. Millennial generations feel that stress level in daily life keep increasing until they feel the need to escape from the stressful conditions. By presenting an architecture that functions as a place and medium for health specializing in mental health for millennials with psychological, recreational, and entertaining methods is expected to help relieving stress in their daily basis. With an approach in pattern language by Christopher Alexander mixed with healing architecture and questionnaire distribution, the design will emphasizes in connectivity between buildings and including natural elements as a merge between natural and artificial environments to have a different result in spatial experience. There is a healing park functioning as public area for natural therapy and is planted with various herbal plants that can help healing psychologically and are expected to be able to relieve everyday exhaustion.
\end{abstract}

Keywords: Cikini; Millennials; Healing; Stress; Therapy 


\section{PENDAHULUAN}

Generasi Milenial (Gen Y) merupakan generasi yang lahir antara tahun 1981 - 1994. Populasi usia produktif saat ini didominasi oleh generasi milenial. Perbedaan yang signifikan adalah kemampuan dalam menguasai informasi dan teknologi melalui internet yang sudah mendunia dan semakin terkoneksi. Dengan perkembangan teknologi mengubah gaya hidup menjadi serba cepat dan instan. Dengan perkembangan modernisasi dan globalisasi mengubah kehidupan sosial dari masyarakat kompleks menjadi multi kompleks dengan gaya hidup serba cepat (fast paced life) yang mengakibatkan sulitnya beradaptasi satu sama lain. Berdasarkan survei Centre for Strategic and International Studies (2017) menunjukkan bahwa sumber kebahagiaan utama adalah kesehatan. Berdasarkan data Vision Critical (2016) menunjukkan bahwa isu tentang ketimpangan kesehatan menjadi peringkat kedua yang penting bagi generasi milenial.

Fast paced life merupakan hidup serba cepat yang sudah menjadi karakteristik dari generasi milenial. Istilah tersebut biasa digunakan dalam gaya hidup urban yang selalu menuntut kegiatan serba cepat dengan aktivitas padat dan terus menerus. Kondisi ini memicu permasalahan kesehatan mental (mental disorder) masyarakat perkotaan, yaitu depresi atau stres yang dapat menyebabkan emosi dan kebiasaan yang tidak stabil.

Berdasarkan data Riset Kesehatan Dasar tahun 2013, sekitar 1,33 juta penduduk DKI Jakarta mengalami stres mencapai $14 \%$ dari total penduduk dengan tingkat stres akut mencapai $1-3 \%$ dan stres berat mencapai $7-10 \%$. Menurut data World Health Organization (2016), sekitar 450 juta di dunia mengalami stres, terdapat sekitar 35 juta orang terkena depresi, 60 juta orang terkena bipolar, 21 juta terkena skizofrenia, dan 47,5 juta terkena dimensia. Di Indonesia, tercatat sekitar 10\% dari total penduduk Indonesia mengalami stres. Berdasarkan data Asia's Least and Most Stresful Cities (2017), Jakarta menempati peringkat ke - 6 kota yang paling stres. Jumlah kasus gangguan jiwa terus meningkat dengan berbagai faktor diantaranya: faktor biologis, psikologis, dan sosial dengan keanekaragaman penduduk.

Berdasarkan survei oleh Mental Health Foundation terhadap 4500 orang mengenai stres di kantor, 34\% kaum milenial merasa stres bila mereka kurang produktif. Hanya $19 \%$ kaum sebelum milenial yang merasa demikian. Sedangkan hanya $14 \%$ yang berani dan menyatakan masalah stresnya kepada atasan. Sebanyak $27 \%$ generasi milenial merasa terganggu dengan stres saat bekerja. Sedangkan pada generasi sebelumnya (Baby Boomers) hanya sebesar $12 \%$. Kondisi kerja yang buruk dan tidak aman dapat menggerogoti kesehatan mental pekerja. Hasil survei menyatakan $32 \%$ orang dewasa merasa ingin bunuh diri akibat stres, dan $16 \%$ orang dewasa telah menyakiti diri sendiri karena stres dimana pelakunya lebih banyak perempuan dan baru memasuki usia dewasa.

Populasi penduduk berpendapatan menengah semakin meningkat dan kebutuhan juga semakin meningkat sehingga banyak dari mereka memilih untuk mengeluarkan pendapatannya yang bersifat sekunder. Generasi milenial ini mengalihkan pengeluarannya dari kategori Fast Moving Consumer Good (FMCG) tradisional seperti makanan dan minuman ke berbagai kategori atau produk lain seperti rekreasi dan liburan, gadget atau produk elektronik, dan data seluler. Hasil Riset Memahami Tren Konsumen Masa Kini yang dilakukan oleh PT Neurosensum Technology International (2008), menuturkan ada beberapa poin penting yang menunjukkan adanya perubahan signifikan dalam perilaku konsumsi di Indonesia yaitu meningkatkan kebutuhan rekreasi pada generasi milenial. Generasi milenial ini merasa bahwa tingkat stres dalam kehidupan sehari - hari semakin meningkat sehingga muncul kebutuhan untuk melarikan diri dari kondisi stres.

Oleh karena itu, untuk meningkatkan kepedulian akan kesehatan mental di kota Jakarta diperlukan wisata hiburan khusus kesehatan dan kebugaran yang disebut sebagai health tourism. Health tourism difokuskan pada program healing dan hospitality. Diharapkan healing center ini sebagai salah satu sarana kesehatan khusus kejiwaan bagi generasi milenial dengan metode psikologis, rekreatif, dan bersifat menghibur khususnya bagi generasi milenial untuk melepaskan kepenatannya sehari - hari. 


\section{KAJIAN LITERATUR}

\section{Tipe}

Berdasarkan etimologi, kata tipe berasal dari bahasa Yunani, "typos", yang berarti model, matriks, jejak pada sebuah figur yang membawa karakter asal yang berhubungan erat dengan hukum universal. Ilmu yang mempelajari tentang impresi, gambaran, bentuk, jenis atau karakter dari suatu objek disebut tipologi. Menurut Christopher Lee dan Sam Jacoby dalam buku Typological Urbanism membagi tipe menjadi dua bentuk dasar, yaitu tipe berupa model dan tipe berupa ide. Pertama kali, tipe berupa model digagas melalui klasifikasi morfologi arsitektur oleh Jean - Nicolas - Louis Durand pada akhir abad ke - 18. Durand memaparkan bahwa tipe merupakan klasifikasi berdasarkan kemiripan morfologis. Setelahnya, Durand memilih untuk menggunakan istilah genre.

\section{Perilaku}

Menurut Kast dan Rosenzweig (1996), perilaku adalah cara bertindak yang menunjukkan tingkah laku seseorang dan merupakan hasil kombinasi antara pengembangan anatomis, fisiologis, dan psikologis. Menurut Notoatmodjo (2003), perilaku dapat dikatakan sebagai apa yang dikerjakan oleh organisme tersebut, baik yang dapat diamati secara langsung maupun tidak langsung. Perilaku manusia ini pada dasarnya berupa aktivitas atau kegiatan manusia sehari - hari seperti: berjalan, berbicara, bereaksi, berpakaian, dll.

\section{Kesejamanan}

Dalam Kamus Besar Bahasa Indonesia (KBBI), zaman adalah jangka waktu yang panjang atau pendek yang menandai sesuatu, masa; kala, waktu. Kesejamanan ini menjadi topik yang diperbincangkan dari tahun ke tahun karena perkembangan zaman dan revolusi industri yang terjadi begitu pesat.

\section{Generasi Milenial}

Tabel 1. Pengelompokkan Generasi

\begin{tabular}{|c|c|c|c|c|c|}
\hline Sumber & & 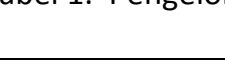 & Label & & \\
\hline $\begin{array}{l}\text { Tapscott } \\
(1998)\end{array}$ & - & $\begin{array}{l}\text { Baby Boom } \\
\text { Generation } \\
(1946-1964)\end{array}$ & $\begin{array}{c}\text { Generation X } \\
(1965-1975)\end{array}$ & $\begin{array}{c}\text { Digital } \\
\text { Generation } \\
(1976-2000)\end{array}$ & - \\
\hline $\begin{array}{l}\text { Howe \& Strauss } \\
(2000)\end{array}$ & $\begin{array}{c}\text { Silent } \\
\text { Generation } \\
(1925-1943)\end{array}$ & $\begin{array}{c}\text { Boom } \\
\text { Generation } \\
(1943-1960)\end{array}$ & $\begin{array}{c}13^{\text {th }} \\
\text { Generation } \\
(1961-1981)\end{array}$ & $\begin{array}{l}\text { Milenial } \\
\text { Generation } \\
(1982-2000)\end{array}$ & - \\
\hline $\begin{array}{l}\text { Zemke et al } \\
(2000)\end{array}$ & $\begin{array}{c}\text { Veterans } \\
(1922-1943)\end{array}$ & $\begin{array}{c}\text { Baby Boomers } \\
(1943-1960)\end{array}$ & $\begin{array}{c}\text { Gen - Xers } \\
(1960-1980)\end{array}$ & $\begin{array}{c}\text { Nexters } \\
(1980-1999)\end{array}$ & - \\
\hline $\begin{array}{l}\text { Lancaster \& Stillman } \\
(2002)\end{array}$ & $\begin{array}{c}\text { Traditionalist } \\
(1900-1945)\end{array}$ & $\begin{array}{c}\text { Baby Boomers } \\
(1946-1964)\end{array}$ & $\begin{array}{c}\text { Generation } \\
\text { Xers } \\
(1965-1980)\end{array}$ & $\begin{array}{l}\text { Generation Y } \\
(1981-1999)\end{array}$ & - \\
\hline $\begin{array}{l}\text { Martin \& Tulgan } \\
(2000)\end{array}$ & $\begin{array}{c}\text { Silent } \\
\text { Generation } \\
(1925-1942)\end{array}$ & $\begin{array}{c}\text { Baby Boomers } \\
(1946-1964)\end{array}$ & $\begin{array}{c}\text { Generation X } \\
(1965-1977)\end{array}$ & $\begin{array}{c}\text { Milenials } \\
(1978-2000)\end{array}$ & - \\
\hline $\begin{array}{l}\text { Oblinger \& Oblinger } \\
(2005)\end{array}$ & $\begin{array}{l}\text { Matures } \\
(<1946)\end{array}$ & $\begin{array}{c}\text { Baby Boomers } \\
(1947-1964)\end{array}$ & $\begin{array}{l}\text { Generation } \\
\text { Xers } \\
(1965-1980)\end{array}$ & $\begin{array}{c}\text { Gen } \\
\text { Y/NetGen } \\
(1981-1995)\end{array}$ & $\begin{array}{c}\text { Post } \\
\text { Milenials } \\
\text { (1995- } \\
\text { present) }\end{array}$ \\
\hline
\end{tabular}

Sumber: Theoritical Review: Teori Perbedaan Generasi, 2016

Menurut Manheim (1952), generasi adalah suatu konstruksi sosial dimana didalamnya terdapat sekelompok orang yang memiliki kesamaan umur dan pengalaman historis yang sama. ${ }^{1}$ Menurut Parry \& Urwin (2011), faktor yang mendasari pengelompokkan generasi adalah faktor demografi (kesamaan tahun kelahiran), dan faktor sosiologis (kejadian - kejadian

\footnotetext{
${ }^{1}$ Mannheim, K. 1952. The Problem of Generations. Essays on the Sociology of Knowledge, 24(19), hal. 276-322 - 24.
} 
yang historis). Namun, Caspi \& Robert (2001) mengungkapkan bahwa kejadian historis, sosial, efek budaya, dan faktor lain akan berpengaruh terhadap terbentuknya perilaku individu, nilai, dan kepribadian.

\begin{tabular}{|c|c|c|c|}
\hline Values & Attitudes & Lifestyle & Personality \\
\hline $\begin{array}{l}\text { Fun and } \\
\text { enjoyment }\end{array}$ & Outcomes not processes & Short term not long term & Confident \\
\hline $\begin{array}{l}\text { Tolerance of } \\
\text { diversity }\end{array}$ & Enjoy the now & $\begin{array}{l}\text { Enjoyment before } \\
\text { commitment }\end{array}$ & Cynical \\
\hline $\begin{array}{l}\text { Social } \\
\text { awareness }\end{array}$ & Sexuality is a fluid thing & Have limited or no savings & Assertive \\
\hline \multirow[t]{4}{*}{ Friendship } & $\begin{array}{l}\text { Organize work around } \\
\text { life, not life around } \\
\text { work }\end{array}$ & $75 \%$ are in debt & High maintenance \\
\hline & $\begin{array}{c}\text { Why should I have to } \\
\text { work my way to the } \\
\text { top? }\end{array}$ & $\begin{array}{l}\text { Half still live in parental } \\
\text { home }\end{array}$ & Demanding \\
\hline & $\begin{array}{l}\text { When it comes to } \\
\text { respecting elders: } \\
\text { "Whaterver! Prove it!" }\end{array}$ & Lifestyle not life stage & Sociable \\
\hline & & $\begin{array}{l}\text { Juggling hectic work and } \\
\text { social life }\end{array}$ & Optimistic \\
\hline
\end{tabular}

Sumber: McCrindle Research, The Generation Map, 2006

\section{Tipologi Generasi Millennial}

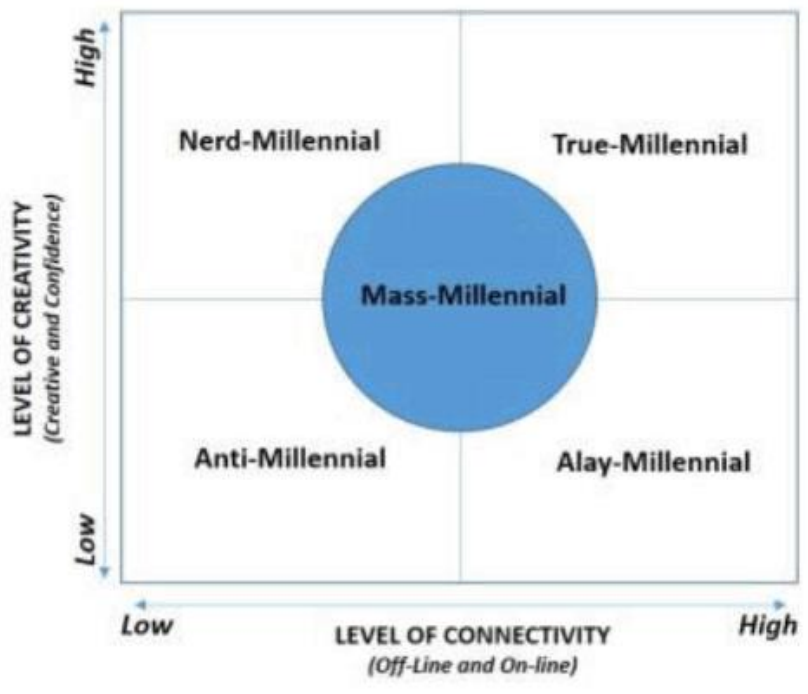

Gambar 1. Tipologi Generasi Milenial

Sumber: Alvara Research Center, 2016

Alvara Research Center (2016) juga mengungkapkan adanya 5 tipologi generasi milenial, yaitu: anti - milenial, mereka yang hanya fisik dan umunya paling milenial tapi perilaku dan karakternya lebih cocok ke generasi sebelumnya; nerd - milenial, mereka yang hidup dalam dunianya sendiri, kreatif tapi kurang gaul, independen, dan konsumsi internet relatif rendah; alay - milenial, mereka yang sangat aktif di sosial media, men - share segala kegiatan yang sedang mereka lakukan; true - milenial, milenial trendsetter, memiliki gadget komplit dan 
tidak bisa lepas dari koneksi internet; dan mass - milenial, memiliki follower yang baik, konsumsi internet menengah, dan kebanyakan aktif di internet berdasarkan personal interest.

\section{Stres}

Menurut Lazarus dan Folkman (1984), stres adalah keadaan internal yang dapat diakibatkan oleh tuntutan fisik dari tubuh atau kondisi lingkungan dan sosial yang dinilai potensial membahayakan, tidak terkendali atau melebihi kemampuan individu untuk melakukan coping. ${ }^{2}$ Menurut Selye (1996), stres diawali dengan reaksi waspada (alarm reaction) terhadap adanya ancaman, ditandai oleh proses tubuh secara otomatis seperti: meningkatnya denyut jantung diikuti reaksi penolakan terhadap stresor dan akan mencapai tahap kehabisan tenaga (exhaustion) jika individu merasa tidak mampu bertahan. Menurut Schafer (2000), menggolongkan stres menjadi tiga golongan atas dasar persepsi individu terhadap stres yang dialaminya yaitu: neustres (stres netral), distres (stress negatif), dan eustres (stres positif).

Tabel 3. Hubungan antara Sindrom Stres, Level Stres, Gejala, Cara Mengatasi, dan Jenis Terapi

\begin{tabular}{|c|c|c|c|c|}
\hline $\begin{array}{c}\text { Sindrom } \\
\text { Stres }\end{array}$ & $\begin{array}{l}\text { Level } \\
\text { Stres }\end{array}$ & Gejala / Keluhan & Cara Mengatasi & Jenis Terapi \\
\hline \multirow[t]{2}{*}{$\begin{array}{l}\text { Tahap } 1 \\
\text { Alarm Stage }\end{array}$} & Tahap I & $\begin{array}{l}\text { Merasa senang, over acting, mampu } \\
\text { menyelesaikan pekerjaan dengan } \\
\text { cadangan energi yang menipis }\end{array}$ & $\begin{array}{l}\text { Berkumpul, } \\
\text { menenangkan diri, } \\
\text { berlatih fisik }\end{array}$ & Terapi fisik \\
\hline & Tahap II & $\begin{array}{c}\text { Mulai hilang rasa bahagia, letih } \\
\text { waktu bangun pagi, lelah sesudah } \\
\text { makan siang, jantung berdebar- } \\
\text { debar, otot punggung tegang, tidak } \\
\text { bisa santai }\end{array}$ & $\begin{array}{l}\text { Menenangkan } \\
\text { pikiran, bersantai, } \\
\text { melawan rasa lelah }\end{array}$ & $\begin{array}{l}\text { Terapi musik, } \\
\text { terapi warna }\end{array}$ \\
\hline \multirow[t]{2}{*}{$\begin{array}{l}\text { Tahap } 2 \\
\text { The Stage of } \\
\text { Resistance }\end{array}$} & Tahap III & $\begin{array}{l}\text { Gangguan usus dan lambung } \\
\text { (gastritis, diare), tegang otot makin } \\
\text { terasa, meningkatnya emosional, } \\
\text { insomnia, sistem koordinasi } \\
\text { terganggu (pingsan) }\end{array}$ & $\begin{array}{l}\text { Meningkatkan } \\
\text { konsentrasi, } \\
\text { menenangkan diri, } \\
\text { berlatih fisik }\end{array}$ & $\begin{array}{l}\text { Relaksasi, } \\
\text { meditasi, } \\
\text { terapi } \\
\text { mandala }\end{array}$ \\
\hline & Tahap IV & $\begin{array}{l}\text { Sulit bertahan hingga waktu sehari, } \\
\text { pekerjaan makin membosankan dan } \\
\text { sulit, tidak mampu merespon secara } \\
\text { memadai, sikap negativisme (tidak } \\
\text { bergairah), menurunnya daya ingat } \\
\text { dan konsentrasi, takut dan cemas } \\
\text { tanpa sebab }\end{array}$ & $\begin{array}{l}\text { Meningkatkan } \\
\text { konsentrasi, } \\
\text { meningkatkan } \\
\text { metabolisme tubuh }\end{array}$ & \\
\hline \multirow[t]{2}{*}{$\begin{array}{l}\text { Tahap } 3 \\
\text { The Third } \\
\text { and The } \\
\text { Final } \\
\text { Stage/The } \\
\text { Exhaustion } \\
\text { Stage }\end{array}$} & Tahap V & $\begin{array}{c}\text { Physical and psychological } \\
\text { exhaustion, tidak mampu } \\
\text { menyelesaikan pekerjaan ringan dan } \\
\text { sederhana, gastro intestinal disorder, } \\
\text { peningkatan rasa takut, cemas, } \\
\text { mudah bingung, merokok }\end{array}$ & $\begin{array}{l}\text { Meningkatkan } \\
\text { konsentrasi, } \\
\text { meningkatkan } \\
\text { metabolisme tubuh, } \\
\text { konsultasi }\end{array}$ & $\begin{array}{l}\text { Relaksasi, art } \\
\text { therapy, } \\
\text { konsultasi, } \\
\text { penanganan } \\
\text { medis }\end{array}$ \\
\hline & Tahap VI & $\begin{array}{l}\text { Jantung berdebar sangat kencang, } \\
\text { susah bernafas, badan gemetar, } \\
\text { dingin, dan keringet bercucuran, } \\
\text { ketiadaan tenaga, pingsan }\end{array}$ & $\begin{array}{l}\text { Menurunkan denyut } \\
\text { jantung, } \\
\text { menenangkan diri, } \\
\text { melakukan kegiatan } \\
\text { santai, konsultasi }\end{array}$ & $\begin{array}{l}\text { Konsultasi, } \\
\text { perawatan }\end{array}$ \\
\hline
\end{tabular}

\footnotetext{
${ }^{2}$ Lazarus, Richard S \& Folkman, Susan. 1984. Stres, Appraisal and Coping. New York.
} 


\section{AVERAGE STRESS LEVEL BY GENERATION}

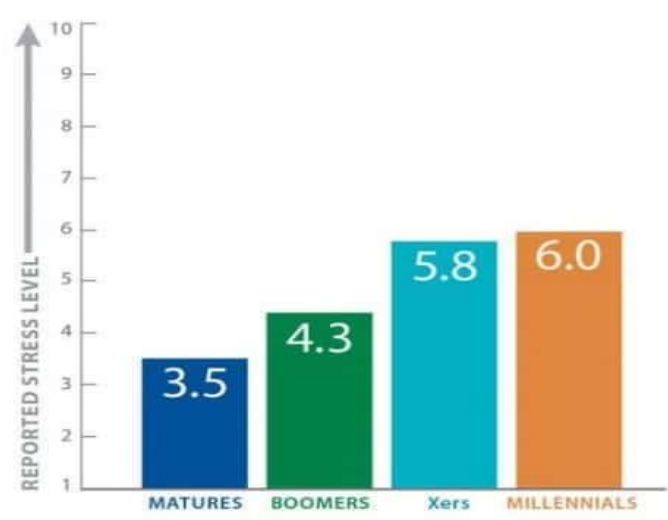

BASE: ALL QUALFED RESPONDENTS 2015 (EEChoesMillennials $n=1190 ;$ : Xers n=649

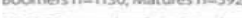

Q605 On a scale of 1 to 10 where I means you have fitrile or no stress" and 10 means you have a great deal of stress," how would you rate your average level of stress during

Gambar 2. Tingkat Stres berdasarkan Generasi

Sumber: https://tech.co/news/milenials-stresing-report-apa-2017-07

Pada gambar 2 menunjukkan tingkat stres generasi milenial mencapai tingkat 6 dari 10, dimana setiap generasi mengalami peningkatan level stres. Cara menanggulangi stres dapat dilakukan dengan beberapa jenis terapi yaitu: terapi mandala, meditasi, terapi warna, art therapy, music therapy, poetry therapy, dance therapy, drama therapy, dan seni visual.

\section{METODE}

\section{Penyebaran Kuesioner}

Penyebaran kuesioner dilakukan melalui google form khusus bagi generasi milenial. Hasil yang didapat sebanyak 60 responden yang mengarah kepada fungsi dan program dari proyek healing center ini.

\section{Pattern Language}

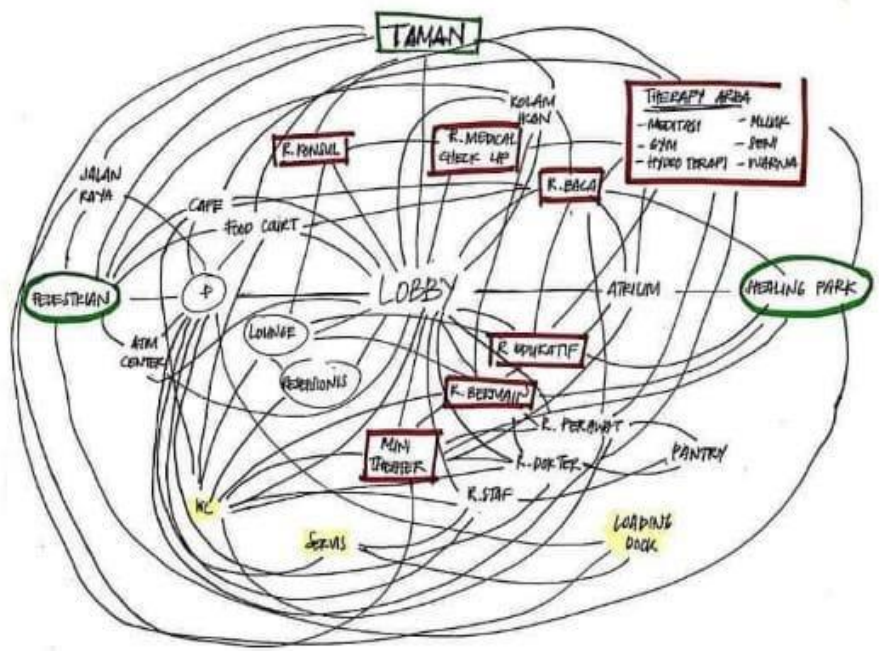

Gambar 3. Pattern Language

Sumber: Penulis 2019 
Pattern Language (bahasa pola) diusulkan oleh Christopher Alexander dan rekannya dan diterbitkan dalam buku "A Pattern Language: Towns, Buildings, Construction" tahun 1977. Buku tersebut berisi aturan tentang berbagai pola dari peletakkan tata ruang kota, peletakkan ruang, sampai detail tiap ruang. Hal ini menggabungkan geometri dengan pola perilaku sosial ke dalam suatu hubungan keruangan sebagai akomodasi aktivitas manusia.

\section{Healing Architecture}

Healing Architecture merupakan salah satu pendekatan dengan tujuan membantu menyembuhkan pengguna dengan penerapan healing environment, salah satu konsep pembentukkan lingkungan perawatan yang memadukan aspek fisik dan psikologis pasien didalamnya untuk mempercepat proses penyembuhan.

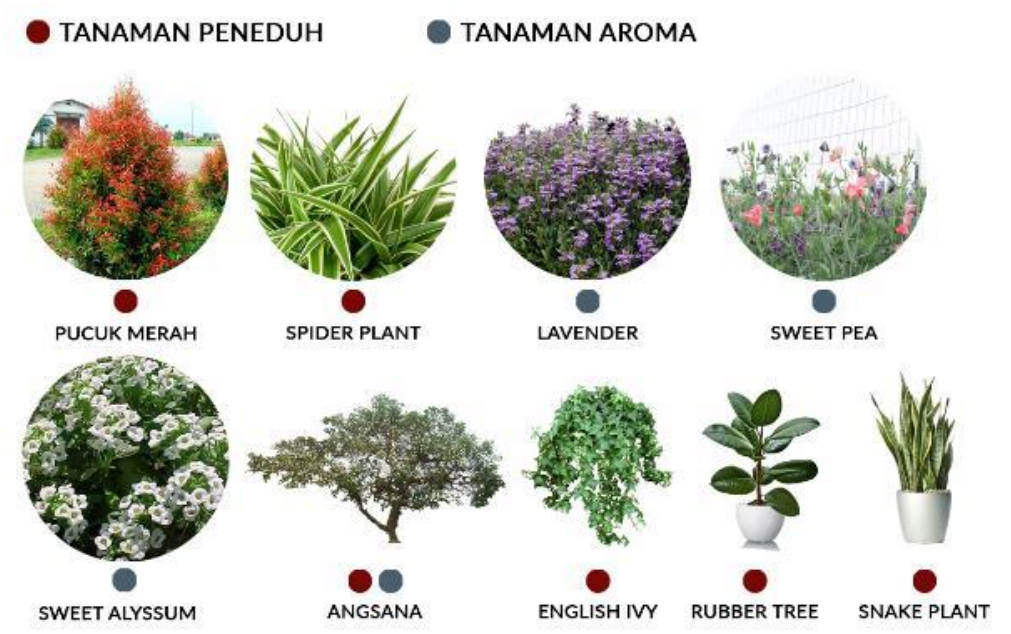

Gambar 4. Jenis Tanaman yang Digunakan Sumber: Penulis, 2019

Jenis tanaman yang digunakan pada proyek ini merupakan tanaman peneduh dan tanaman aromaterapi. Tanaman peneduh diantaranya: pucuk merah, spider plant, angsana, english ivy, rubber tree, dan snake plant. Sedangkan untuk tanaman aromaterapi yang dapat menenangkan jiwa dan pikiran diantaranya: lavender, sweet pea, dan sweet alyssum. Tidak hanya di taman saja, melainkan di dalam ruangan juga diciptakan taman dan diberi tanaman untuk memberikan suasana hijau dan terkesan menyatu dengan alam.

\section{DISKUSI DAN HASIL}

Proyek berupa sebuah wadah sarana kesehatan khusus kejiwaan bagi generasi milenial dengan metode psikologis, rekreasi, dan bersifat menghibur untuk meredakan stres akibat perubahan pola hidup yang serba cepat dan instan. Dari pendekatan yang digunakan kemudian diolah, dianalisis, dan digunakan sebagai acuan dasar dalam mendesain proyek. 


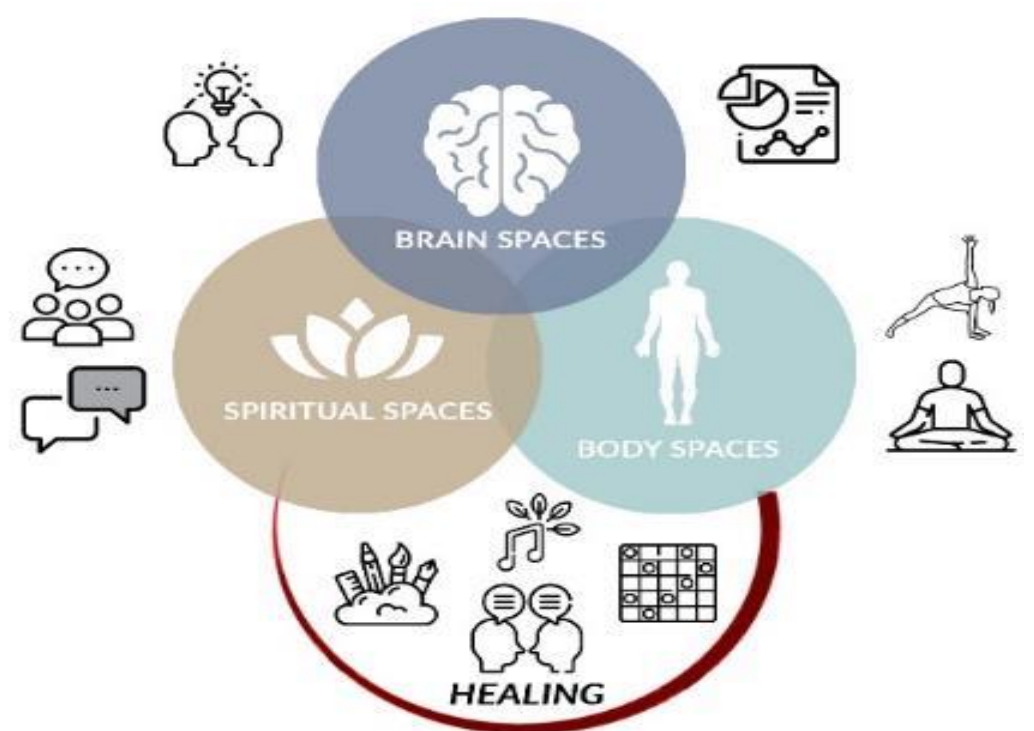

Gambar 5. Ilustrasi Konsep Perancangan Sumber: Penulis, 2019

Konsep desain proyek ini terinspirasi dari siklus hidup manusia. Siklus hidup manusia merupakan rutinitas yang dilakukan oleh masing - masing individu di setiap harinya. Kondisi ini yang memicu ketidakstabilan organ tubuh baik pikiran, jiwa, dan raganya. Apabila salah satu mengalami gangguan, maka pribadi tersebut akan merasa tidak nyaman, stres, depresi, dan bahkan bunuh diri. Dari ketiga elemen yang ada di setiap manusia ini harus seimbang. Setelah diolah dan dianalisis dengan menggabungkan ilmu psikologis, hasil kuesioner, dan pattern language, muncullah beberapa program yang ditujukan khusus bagi generasi milenial.

Dari pendekatan pattern language, terbentuk pola baru yang disesuaikan dengan organisasi ruang dan diimplementasikan ke dalam gubahan dan disesuaikan kembali dengan konsep dan kebutuhan ruang. Organisasi ruang ini menjadikan pembentukkan ruang ke ruang. Berdasarkan alur kegiatan, organisasi ruang terdiri dari alur kegiatan pengunjung, alur kegiatan pasien, alur kegiatan staff ahli (dokter/psikolog/psikiater/perawat), dan alur kegiatan karyawan/pengelola. Organisasi ruang tersebut kemudian diimplementasikan ke dalam gubahan massa dan tercipta ruang - ruang pada massa bangunan seperti pada gambar 7 .

Penerapan healing environment ini merupakan salah satu konsep pembentukkan lingkungan yang menggabungkan aspek fisik dan psikologis pasien untuk mempercepat proses penyembuhan. Dalam arsitektur diterapkan sebagai suatu elemen pendukung dalam membantu proses penyembuhan seorang pasien yang didalamnya mengintegrasikan indera, psikologis, dan alam. Maka dari itu, diberikan taman yang terjaga privasinya di sisi timur bangunan. Dengan demikian, para pasien dapat menenangkan diri sejenak dan dapat menikmati suasana alam di tengah hiruk pikuk kota yang padat dengan menghirup aromaterapi dari tanaman. 


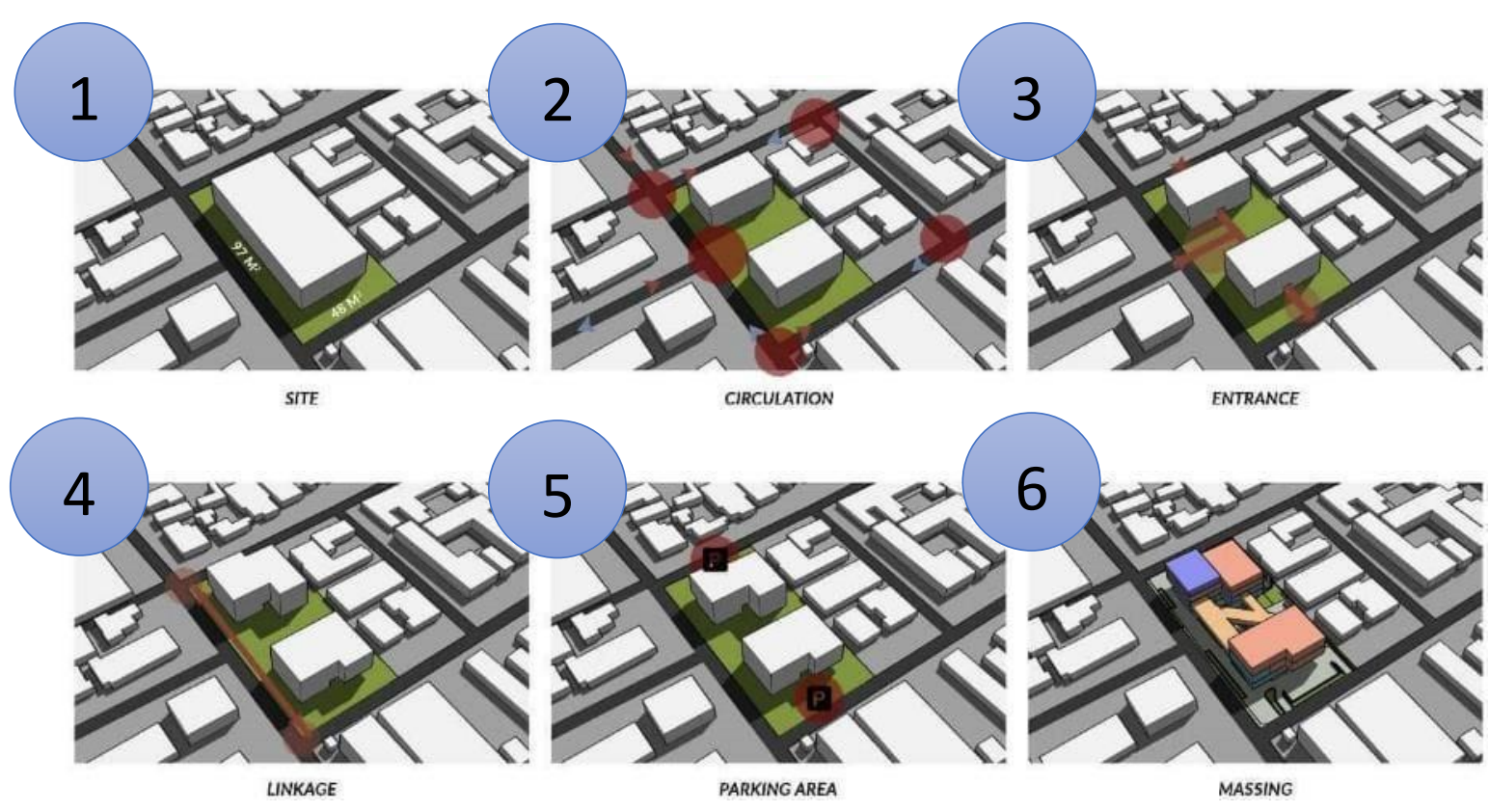

Gambar 6. Design Scheme

Sumber: Penulis, 2019

Hasil analisis tapak kemudian diimplementasikan menjadi proses desain sebagai berikut:

1. Tapak memiliki gsb 8 meter di setiap sisinya. Massa bangunan dimaksimalkan dengan dipotong garis sepadan bangunan. Ketentuan peruntukan bangunan dari RDTR pada tapak terdiri dari:

$\begin{array}{lllllll}\text { KDB } 60 & \text { KLB } & 2,4 & \text { KB } & 4 & \text { KDH } & 30 \\ \text { Zona Campuran } & \text { KTB } & 55 & \text { Tipe Deret } & \text { PSL Padat }\end{array}$

2. Massa bangunan dibagi menjadi 2 bagian yang sejajar dengan Jalan Ciliman sehingga bangunan menjadi 2 sisi di antara ruang hijau (healing park) dan amphitheather.

3. Entrance pada bangunan berada di ketiga sisi jalan yaitu: sisi utara (Jalan Ciasem), sisi barat (Jalan Cimandiri), dan sisi selatan (Jalan Cidurian).

4. Massa bangunan di tarik dan di dorong untuk memberi kesan dinamis dan tidak monoton, serta mempertimbangkan mayoritas pejalan kaki berada di sisi barat.

5. Parkir kendaraan roda empat berada di ground floor untuk mempermudah akses bagi para pasien sehingga massing dimundurkan. Sedangkan untuk parkir khusus karyawan dan motor berada di basement.

6. Massing akhir kemudian disesuaikan dengan zoning dan program, serta diberi jembatan penyatu antar massa bangunan sebagai ruang transisi.

Penyusunan program pada perancangan ini berorientasi pada bagian tengah tapak yaitu amphitheather dan healing park yang dapat diakses langsung dari jalur pedestrian dan juga merupakan area titik kumpul. Hal ini untuk mengarahkan pengunjung dapat langsung melihat ke dalam tapak yang berupa taman (healing park) dari sisi Jalan Ciliman. Pada gambar 7 di bawah ini menunjukkan zoning tiap lantai pada bangunan ini. 


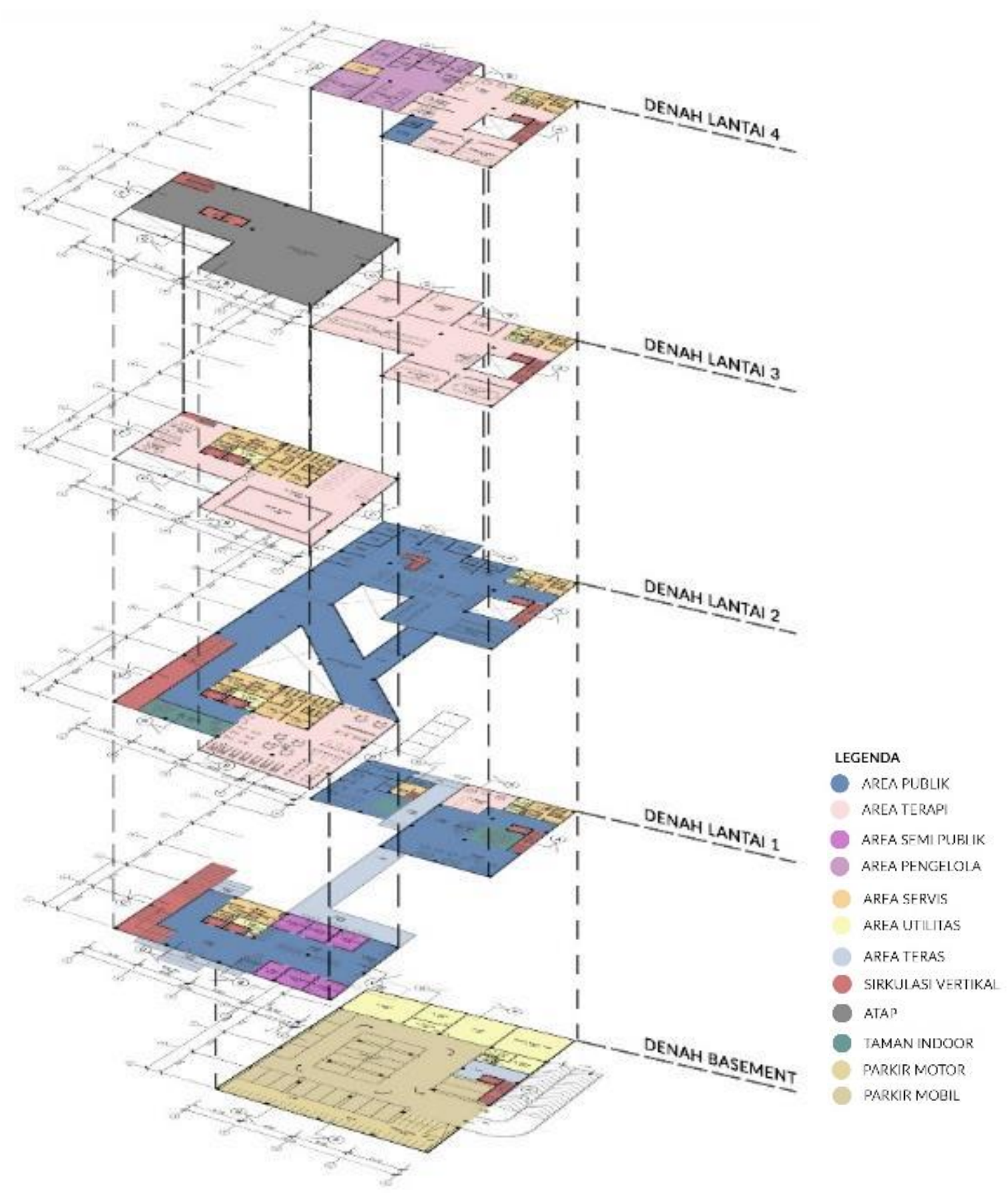

Gambar 7. Exploded Denah

Sumber: Penulis, 2019

Pada massa bangunan di sebelah selatan merupakan area bagi para pasien untuk berkonsultasi, sedangkan massa bangunan di sebelah utara merupakan area terapi dan area penunjang yang berupa cafe, foodcourt, dan atm center. Pada lantai 3 dan 4 terdapat area terapi di antaranya: terapi air, terapi musik, meditasi, art therapy berupa ruang seni lukis, dan ruang sharing, serta fasilitas lainnya seperti ruang bermain, ruang baca, minitheather, dan ruang edukatif bagi mereka yang melakukan workshop mengenai kesehatan dan cara menangani stres yang cepat, tepat, dan efisien. 


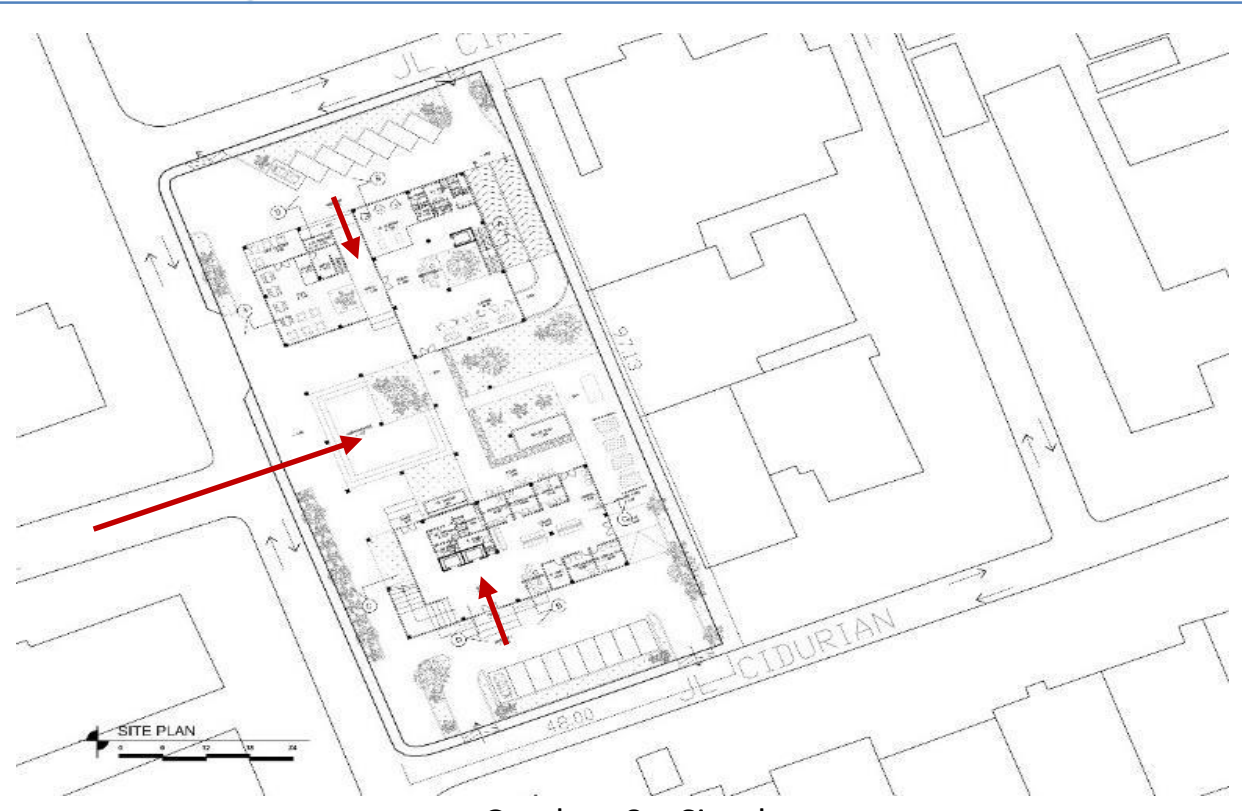

Gambar 8. Siteplan

Sumber: Penulis, 2019

Entrance ke dalam tapak berada di ketiga sisi jalan yang diintegrasikan dengan amphitheather dan healing park di tengah tapak. Untuk entrance ke bangunan berada di kedua sisi jalan, dan entrance dari Jalan Cimandiri langsung menuju ke amphitheather dan healing park. Bagian sisi Jalan Cimandiri ini juga diutamakan bagi para pejalan kaki sehingga akses kendaraan berada di Jalan Ciasem dan Jalan Cidurian.

Untuk menggabungkan kedua massa bangunan terdapat ruang transisi berupa jembatan penghubung yang terinspirasi dari siklus hidup manusia yang terus menerus berulang dan terintegrasi satu sama lain. Pada jembatan tersebut, pengunjung dan pasien dapat menikmati healing park dari atas, menenangkan pikiran, bersantai, dan juga dapat saling berkomunikasi satu sama lain. Pada healing park dan amphitheather dapat berkomunikasi dan berkonsultasi baik kepada para ahli atau group sharing sehingga dapat memberikan suasana yang berbeda dan menjadi self healing bagi para pasien.

Material yang digunakan bernuansa alam dan memiliki warna yang tidak mencolok seperti: parket kayu, second skin GRC dengan motif batu bata expose, beton expose, kisi - kisi aluminium yang dilapisi warna kayu, dan curtain wall. Pada sudut - sudut ruangan juga terdapat pot tanaman untuk memberikan efek hijau di dalam bangunan dan memberikan aromaterapi alami.
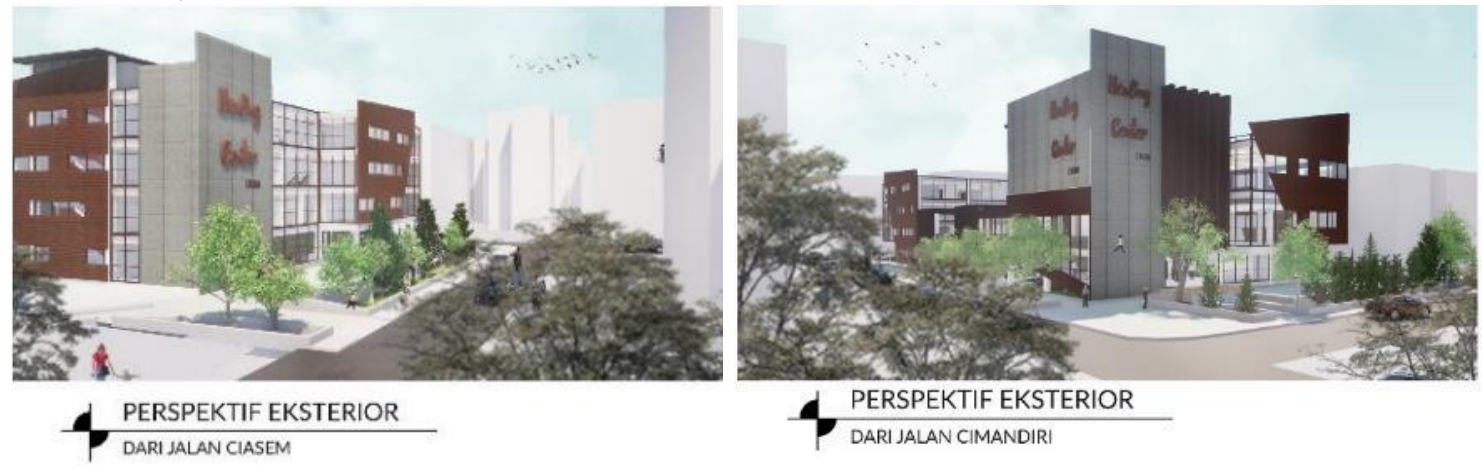

Gambar 9. Perspektif Ekterior dari Jalan Ciasem dan Cimandiri Sumber: Penulis, 2019 


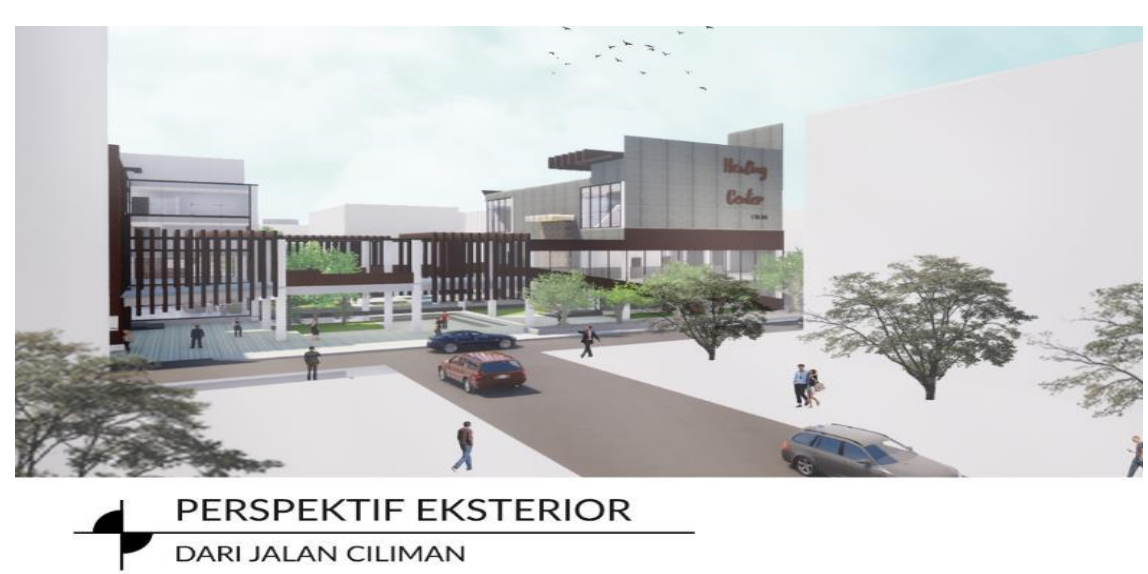

Gambar 10. Perspektif Ekterior dari Jalan Ciliman

Sumber: Penulis, 2019

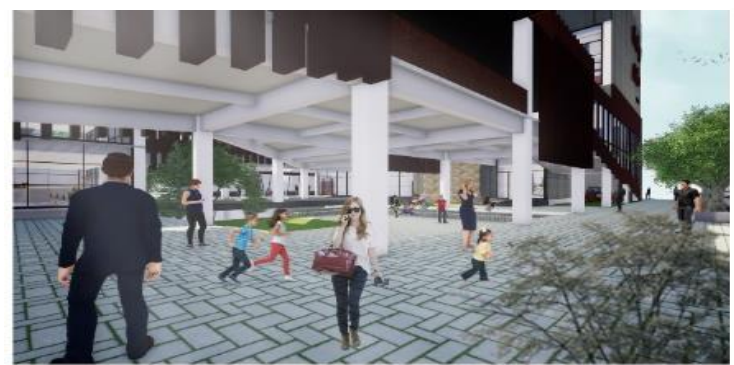

PERSPEKTIF EKSTERIOR

Gambar 11. Perspektif Ekterior Amphitheater dan Healing Park Sumber: Penulis. 2019

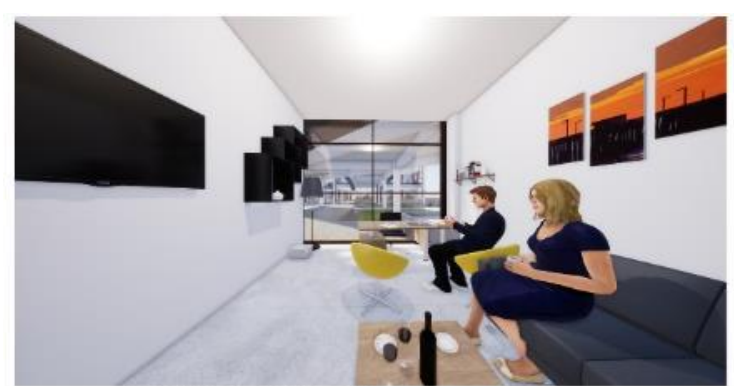

PERSPEKTIF INTERIOR

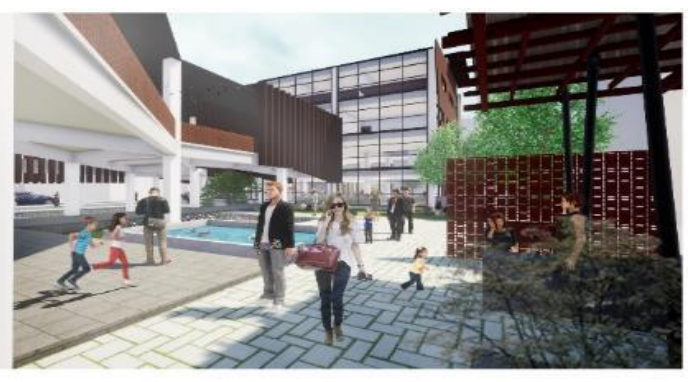

PERSPEKTIF EKSTERIOR

Gambar 12. Perspektif Interior Ruang Konsultasi dan Ruang Bermain Sumber: Penulis, 2019

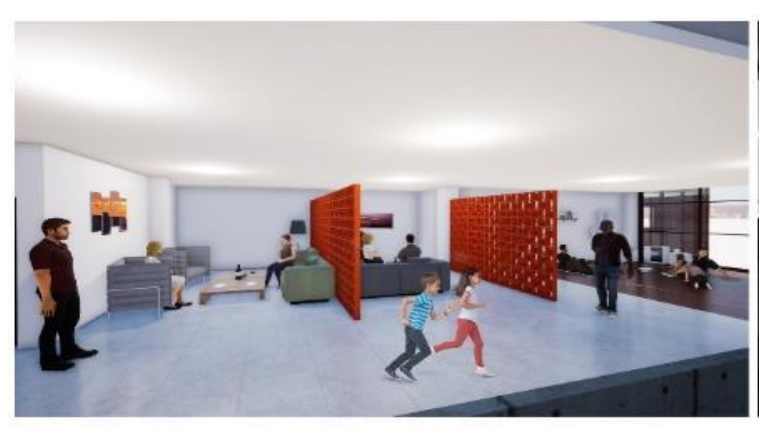

PERSPEKTIF INTERIOR

RUANG SHARING DAN RUANG BACA

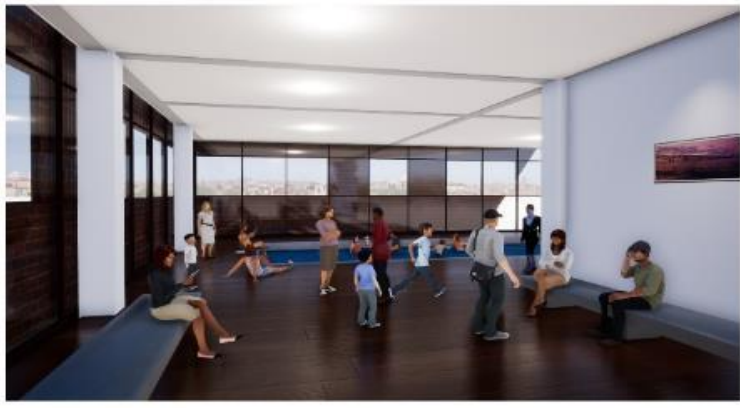

PERSPEKTIF INTERIOR
RUANG TERAPIAIR

Gambar 13. Perspektif Interior Ruang Sharing dan Ruang Terapi Air Sumber: Penulis, 2019 

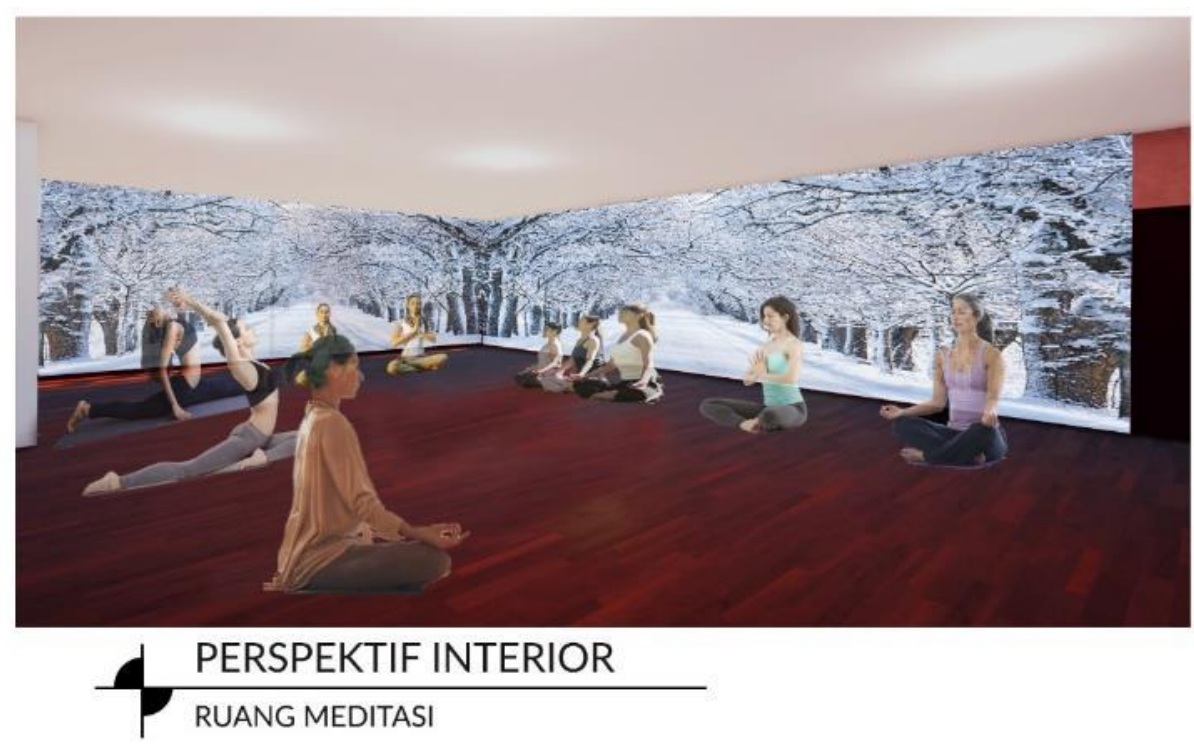

Gambar 14. Perspektif Interior Ruang Meditasi Sumber: Penulis, 2019

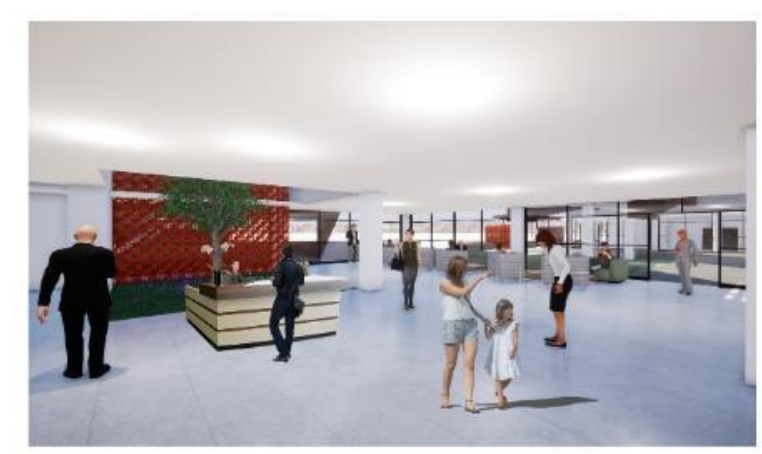

PERSPEKTIF INTERIOR LOBBYUTARA

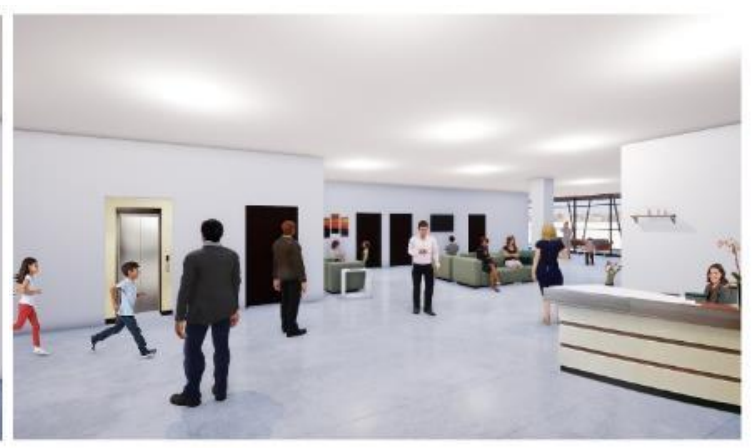

PERSPEKTIF INTERIOR

Gambar 15. Perspektif Interior Lobby Utara dan Lobby Selatan Sumber: Penulis, 2019

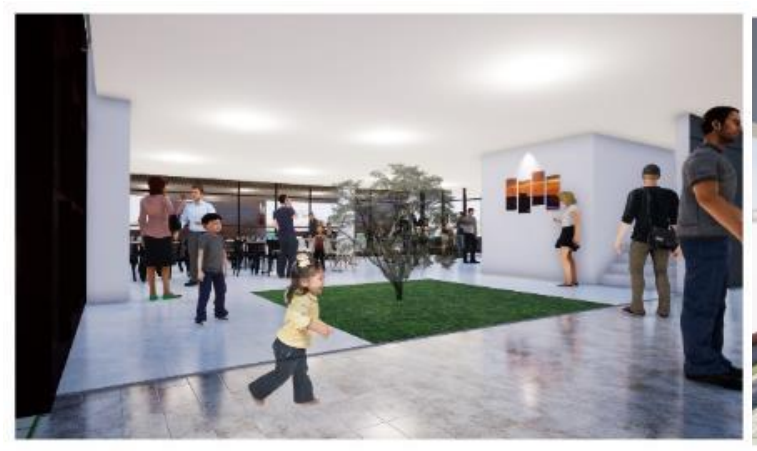

PERSPEKTIF INTERIOR

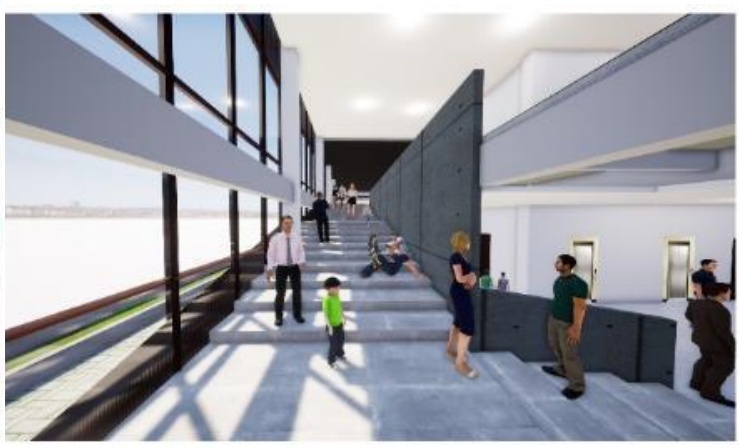

PERSPEKTIF INTERIOR
TANGGA MENUJU BRIDGE

Gambar 16. Perspektif Cafe dan Tangga Menuju Bridge

Sumber: Penulis, 2019 


\section{KESIMPULAN DAN SARAN \\ Kesimpulan}

Perubahan pola hidup generasi milenial saat ini berpengaruh terhadap kesehatan baik kesehatan pikiran, jiwa, dan raga. Isu mengenai ketimpangan kesehatan ini menjadi masalah kedua yang diperhatikan oleh generasi milenial. Dengan gaya hidup mereka yang serba cepat dan instan (fast paced life) ini menjadi salah satu faktor pemicu kesehatan psikisnya. Dengan meningkatnya populasi berpendapatan menengah menimbulkan perubahan perilaku konsumsi di Indonesia yang mengarah ke berbagai kategori yang bersifat sekunder. Oleh karena itu, untuk meningkatkan kepedulian akan kesehatan mental di kota Jakarta diperlukan sarana hiburan khusus untuk kesehatan dan kebugaran yang disebut dengan health tourism.

Dengan mendesain sebuah bangunan berdasarkan tipologi dan perilaku generasi milenial, maka akan menciptakan sebuah output arsitektur yang sangat cocok bagi generasi milenial sebagai target utama proyek ini. Dengan penggabungan hasil kuesioner yang dilakukan, penerapan pattern language, dan ilmu psikologis dapat membantu dalam menentukan dan mengorganisasikan program apa saja yang tepat dan sesuai bagi generasi milenial.

Dari perilaku dan karakteristik generasi milenial yang terbuka dan senang berdiskusi, maka diciptakan ruang - ruang untuk sharing baik di dalam maupun di luar bangunan. Untuk program utama dalam healing center ini antara lain: terapi air, terapi musik, meditasi, art therapy berupa ruang seni lukis, dan ruang sharing, serta fasilitas lain yang didapat dari perilaku dan karakteristik generasi milenial berupa ruang bermain, ruang baca, minitheather, dan ruang edukatif untuk memberikan informasi terkait kesehatan, dan cara menanganinya dengan cepat, tepat, dan efisien.

Dari penerapan healing architecture, diterapkan dalam bentuk ruang terbuka di luar bangunan dalam bentuk amphitheater dan healing park yang ditanami oleh berbagai tanaman peneduh dan aromaterapi yang dapat membantu penyembuhan secara alamiah baik secara fisik maupun psikologis. Selain itu juga diciptakan ruang hijau di dalam bangunan sehingga pasien atau pengunjung merasakan ruang dalam seperti berada di ruang luar.

\section{Saran}

Adanya penambahan program - program baru di dalam bangunan agar dapat meningkatkan kualitas pelayanan kesehatan baik dalam bangunan maupun di luar bangunan. Menambahkan kapasitas ruang di setiap program untuk memperluas radius pelayanan. Meningkatkan kualitas ruang terbuka hijau sebagai metode penyembuhan secara alamiah.

\section{REFERENSI}

Afrillia, D. (2017, Juni 21). Ini Sebab Milenial Stres dan Tidak Produktif. Dipetik dari 7 Januari 2019, dari https://beritagar.id/artikel/gaya-hidup/ini-sebab-milenial-stres-dan-tidakproduktif

Alexander, C. (1979). A Pattern Language. New York: Oxford University Press.

Ali, H. (2016). Memahami Milenial Indonesia. Alvara Research Center.

Atkinson, S., dkk. (2000). Introduction to Psychology (13 ${ }^{\text {th }}$ Edition). Harcourt College Publisher.

Beckwith, P. M. (2014). Mindfulness and Mandalas: Alternative Therpeutic Techniques for AOD

Adolescents. Capital University's Undergraduate Research Journal.

Choices, F. (2017). Slow Movement [Online]. Available: www.slowmovement.com

Duffy. (2016). Millennial Myths and Realities. Ipsos Mori.

Kast, F.E. \& Rosenzweig, J. (1996). The Social Psychology of Organizations. New York: Wiley. Kemper, K. J. \& Danhauer, S. C. (2005). Music as Therapy. Southern Medical Association.

Koran SINDO, Jurnalis. (2018, Mei 17). Riset: Tingkat Stres Ubah Pola Konsumsi Generasi Milenial di Indonesia. Dipetik 6 Januari 2019, dari 
https://lifestyle.okezone.com/read/2018/05/17/196/1899434/riset-tingkat-stresubah-pola-konsumsi-generasi-milenial-di-indonesia

Lazarus, Richard S \& Folkman, Susan. (1984). Stres, Appraisal and Coping. New York.

Lee, C. 2014. A Study on Color Art Therapy based Serious Games. Advanced Science and Technology Letters, Volume 65, 26-30.

Malchiodi, C. A. (2003). Handbook of Art Therapy. New York: Guilford Press.

Murphy, J. (2008). The Healing Environment [Online]. Available:http://arch.ttu.edu.

Notoatmodjo, S. (2003). Pengantar Perilaku Kesehatan. Jakarta: Fakultas Kesehatan Masyarakat, Universitas Indonesia.

Putri, Tiara. (2018, Mei 15). Generasi Milenial Ternyata Lebih Mudah Merasa Stres di Kantor, Apa Penyebabnya? Dipetik 6 Januari 2019, dari https://lifestyle.okezone.com/read/2018/05/15/196/1898687/generasi-milenialternyata-lebih-mudah-merasa-stres-di-kantor-apa-penyebabnya

Skinner, B.F. (1938). The Behavior of Organisms: An Experimental Analysis. Cambridge Massachusetts: B.F. Skinner Foundation. ISBN 1-58390-007-1, ISBN 0-87411-487-X.

Putra, Y. S. (2016). Theoritical Review: Teori Perbedaan Generasi.

http://inkemaris.com/press-releases/controlling-anxiety-for-better-quality-of-life/

http://www.pewresearch.org/topics/milenials/

http://www.zipjet/co/uk/2017-stresful-cities-ranking

https://tech.co/news/milenials-stresing-report-apa-2017-07 
